•研究报告・

\title{
2010-2020年中华穿山甲在中国的发现记录及保护 现状
}

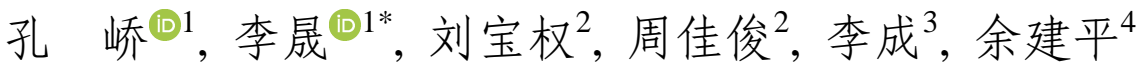

1. 北京大学生命科学学院, 北京 100871; 2. 浙江省森林资源监测中心, 浙江省湿地与野生动植物资源监测中心, 杭州 310020; 3. 西子江生 态保育中心, 广东深圳 518114; 4. 钱江源国家公园管理局, 浙江开化 324300

摘要: 中国是中华穿山甲(Manis pentadactyla)历史分布区面积和野生种群数量最大的国家。中华穿山甲曾广泛见于我国长江 以南各省, 但20世纪中期以来, 由于其甲片被作为贵重的中药材原料, 加之地下野味市场的需求, 大量非法捕猎使得我国野 生穿山甲经历了剧烈的分布区缩减和种群下降。目前, 中华穿山甲已被列为我国一级重点保护野生动物, 在IUCN红色名录中 被评估为极危 $(\mathrm{CR})$ 等级。中华穿山甲分布范围广、种群密度低、活动隐秘、调查难度大，摸清其野外分布现状是当前穿山甲 研究与保护中的首要任务。为此，本研究通过检索2010-2020年间全国范围内中华穿山甲的发现记录，统计中华穿山甲的目击 数量、空间分布以及后续状态，制作物种分布地图，并与历史分布情况进行对比，以评估其野生种群的分布现状与分布区变 化。2010-2020年共在11个省级行政区收集到中华穿山甲确认记录142条, 主要集中于大陆华东地区及台湾岛, 台湾、浙江、 广东三省记录位点数占全部位点数的 $67.6 \%$; 相较其历史分布区，西南、华南地区近年来野外确认较为匮乏。近 10 年来我国 的中华穿山甲记录呈逐渐增多趋势，86\%被发现的实体穿山甲得到救助、放归或未被干扰。本研究结果表明，目前中华穿山 甲在我国，尤其是华东及台湾地区，仍具有一定数量的野生种群分布，且近年来民众对于穿山甲的认知和保护意识有了较大 提高。然而, 现有调查和资料仍不足以对该物种进行全面的现状评估, 亟需加强对我国野生穿山甲种群的调查、监测和保护。 关键词: 中华穿山甲; 分布图; 分布范围; 红外相机; 野生动物监测

孔玥峤, 李晟, 刘宝权, 周佳俊, 李成, 余建平 (2021) 2010-2020年中华穿山甲在中国的发现记录及保护现状. 生物多样性, 29, 910-917. doi: 10.17520/ biods.2020446.

Kong YQ, Li S, Liu BQ, Zhou JJ, Li C, Yu JP (2021) Distribution records and conservation status of Chinese pangolin (Manis pentadactyla) in China during 2010-2020. Biodiversity Science, 29, 910-917. doi: 10.17520/biods.2020446.

\section{Distribution records and conservation status of Chinese pangolin (Manis pentadactyla) in China during 2010-2020}

Yueqiao Kong ${ }^{\circledR 1}$, Sheng $\mathrm{Li}^{\circledR 1 *}$, Baoquan $\mathrm{Liu}^{2}$, Jiajun $\mathrm{Zhou}^{2}$, Cheng $\mathrm{Li}^{3}$, Jianping $\mathrm{Yu}^{4}$

1 School of Life Sciences, Peking University, Beijing 100871

2 Zhejiang Forest Resources Monitoring Center, Zhejiang Wetland and Wildlife Resources Monitoring Center, Hangzhou, 310020

3 Xizijiang Conservation Center, Shenzhen, Guangdong 518114

4 Qianjiangyuan National Park Administration, Kaihua, Zhejiang 324300

\section{ABSTRACT}

Aims: China has the largest historical distribution area and wild population of Chinese pangolin (Manis pentadactyla), which was once widespread, occurring in most provinces south of the Yangtze River in China. However, body parts of Chinese pangolin have been long considered as valuable materials of traditional Chinese medicine and there are also high demands for them as bush meat in the black market. Therefore, since the mid-20th century, wild pangolins in China have experienced dramatic range reduction and population decline due to high pressure of unsustainable, mostly illegal hunting. At present, Chinese pangolin has been recently uplisted as Class-I National Key Protected Wildlife in China and assessed as critically endangered (CR) in the IUCN Red List. As a widely distributed but elusive mammal

收稿日期: 2020-12-01; 接受日期: 2021-02-04

基金项目：生态环境部生物多样性调查、观测与评估项目(2019HJ2096001006)

* 通讯作者 Author for correspondence. E-mail: shengli@pku.edu.cn 
species that inhabits in dense forests and is naturally at low density, Chinese pangolins are challenging wildlife for researchers to investigate. Therefore, there is an urgent need for researchers and conservationists to determine their distribution in the wild, which will provide fundamental bases for further research and conservation activities.

Methods: In this study, we conducted a comprehensive literature research on the occurrence records of Chinese pangolins between 2010 and 2020. We retrieved information from various sources on the time, location and type of record of each event, and generated the occurrence map and compared it with the historical range.

Results: Between 2010 and 2020, we identified 142 confirmed records of Chinese pangolins from 11 provincial administrative regions, mainly distributed in East China and Taiwan Island, with $67.6 \%$ of the occurrence sites were from three provinces (i.e., Taiwan, Zhejiang and Guangdong) across this region. When compared with its historical range, few field records were reported in Southwest and South China. However, during the past decade, the annual number of Chinese pangolins records has been gradually increasing, with $86 \%$ of found individuals being rescued, released on site or undisturbed.

Conclusions: These results indicated that wild populations of Chinese pangolin still persist in China, especially in East China and Taiwan Island. Public awareness of pangolin protection in recent years has been greatly improved. However, the existing surveys and data are insufficient to conduct comprehensive assessment of the status of pangolins in China, and there is an urgent need of field investigation, systematic monitoring and strengthened protection on these wild populations. The results of this study updated our knowledge on the distribution status of Chinese pangolins in China, and will provide essential baseline and information for future conservation planning and further study of this species.

Key words: Manis pentadactyla; range map; distribution range; camera-trapping; wildlife monitoring

穿山甲是鳞甲目穿山甲科哺乳动物的统称，现 存3属8种(https://www. iucnredlist.org/)。其中, 穿山 甲属(Manis)主要分布在亚洲, 长尾穿山甲属 (Phataginus)和地穿山甲属(Smutsia)主要分布在撒 哈拉以南的非洲地区(Gaudin et al, 2009)。亚洲有4 种穿山甲分布, 其中中华穿山甲 (Manis pentadactyla) 分布于中国、不丹、印度、老挝、越 南、泰国、尼泊尔和孟加拉国, 印度穿山甲 $(M$. crassicaudata)分布于孟加拉国、印度、尼泊尔、巴 基斯坦、斯里兰卡和中国, 马来亚穿山甲 $(M$. javanica)分布于文莱、柬埔寨、印度尼西亚、老挝、 马来西亚、缅甸、新加坡、泰国、越南和中国, 菲 律宾穿山甲(M. culionensis)仅分布在菲律宾(吴诗宝 等, 2002)。根据《中国哺乳动物多样性及地理分布》 (蒋志刚等, 2015)与 《中国哺乳动物多样性(第2版)》 (蒋志刚等, 2017), 中国境内共记录有3种穿山甲, 即中华穿山甲、印度穿山甲和马来亚穿山甲。其中 中华穿山甲(亦称穿山甲或中国穿山甲)分布最广, 包括3个亚种: 指名亚种(M. p. pentadactyla), 分布 于台湾; 华南亚种 (M. p. aurita), 主要分布在长江 以南各省; 海南亚种(M. p. pusilla)分布于海南(汪松, 1998; 王应祥, 2003)。印度穿山甲和马来亚穿山甲 历史记录于云南边境部分地区(吴诗宝等, 2002; 王 应祥, 2003; 刘少英等, 2020), 在我国境内的分布与 种群现状不甚清楚。
由于非法捕猎、栖息地丧失等原因, 过去数十 年间全球范围内穿山甲数量急剧下降(张立等, 2010)。我国传统的中医药对穿山甲制品(以甲片为 主)的使用以及地下野味市场的需求, 导致穿山甲 野外种群锐减(Heinrich et al, 2016)。根据原国家林 业局的调查, 在1998年左右, 全国穿山甲原野外种 群数量约有64,000只(国家林业局, 2008); 而Zhang 等(2009)调查认为, 到2008年, 中国野生穿山甲的 数量约在25,100-49,450 只之间。可见1998-2008的 十年间全国范围内穿山甲野生种群数量有大幅度 的下降。近年来, 我国对中华穿山甲的大范围野外 资源调查较少, 根据针对部分省区的物种资源调查 可知, 我国野外穿山甲数量和范围在不断缩减(余 经裕等, 2016; 范宗骥等, 2019)。为进一步加强对穿 山甲的保护力度, 2020 版《中国药典》中, 穿山甲未 被作为中药材继续收录(国家药典委员会, 2020)。 2021年2月发布的《国家重点保护野生动物名录》 中, 穿山甲属动物的保护级别由国家二级重点保护 提升至一级(国家林业和草原局农业农村部公告 (2021年第3号), http://www.forestry.gov.cn/)。

由于目前对野生中华穿山甲生态学、生物学深 入细致的研究十分有限, 加之其繁殖率低、食性特 化且对栖息地要求高, 使得该物种的迁地保护工作 十分困难(Hua et al, 2015)。台北动物园是世界上第 一个实现中华穿山甲人工繁育的动物园(Yang et al, 
2007)。截至目前，中国大陆地区还没有可长期自我 维持的中华穿山甲圈养种群。近年来, 对中华穿山 甲的研究主要集中于非法贸易相关领域以及人工 繁育研究, 而关于中华穿山甲在全国范围内野外种 群资源分布的研究较为匮乏(Cheng et al, 2017; Yang et al, 2018)。中华穿山甲分布现状及动态信息 的匮乏, 成为该物种的保护规划制定与保护行动开 展所面临的亟需解决的问题。

本研究针对我国境内分布范围最广的中华穿 山甲，通过系统检索全国范围内2010-2020年间该 物种的发现记录, 统计中华穿山甲的目击数量、空 间分布以及后续状态，制作物种分布地图，并与历 史分布情况进行对比, 以评估我国中华穿山甲野生 种群的分布现状与分布区变化, 并提出相应的研究 和保护建议。

\section{材料与方法}

在中国知网 (http://www.cnki.net/)中分别使用 “穿山甲” “中华穿山甲” “中国穿山甲” “pangolin” “Manis pentadactyla”作为检索词进行学术论文检索, 在谷歌学术 (www.scholar.google.com) 中使用 “pangolin” “China” “Manis pentadactyla”进行检索, 在中国自然保护区标本资源共享平台 (http://www.papc.cn/html/folder/1-1.htm) 使用 “穿山 甲” “中华穿山甲” “中国穿山甲”进行检索，在中国 裁判文书网(https://wenshu.court.gov.cn/)使用“穿山 甲” “中华穿山甲” “中国穿山甲” “实体”进行检索， 在百度新闻 (https://news.baidu.com/) 、必应 (https://cn.bing.com/) 、 谷 歌 (https://www.google. com.hk/)中使用“穿山甲” “中华穿山甲” “中国穿山 甲”进行检索，识别出2010-2020年已发表的有关中 华穿山甲的中文和英文文献、司法判决文书、新闻 报道等资料, 收集整理有关中华穿山甲的红外相机 拍摄、实体目击或捕获救助记录。虽然近 10 年来中 华穿山甲的保护和研究力度在加强, 但大量结果还 未以文献形式发表, 因此我们也收集整理了本文作 者所主持的红外相机调查与其他野外调查数据中 未发表的中华穿山甲确认记录。

对所有记录进行审核, 删除重复、信息模糊及 走私入境的相关记录。对于罚没个体和标本, 确定 其最初野外捕捉或采集地点; 若无法确认, 则作为 模糊信息删除。对剩余的确认记录，提取每条记录
里中华穿山甲的数量、出现的地理位置(如有GPS坐 标点则直接提取位点的经纬度坐标; 如果没有精确 坐标点, 则根据发现地点的小地名, 在百度地图或 Google Earth中查询获得发现地点的大致经纬度坐 标)、身体状态、后续去向、出现原因等信息，在 ArcGIS 10.5中生成确认记录分布点的矢量点图层, 作为中华穿山甲的当前分布点; 根据IUCN最新物 种分布数据(https://www.iucnredlist.org/), 提取中华 穿山甲在我国的分布情况(Challender et al，2019); 使用ArcGIS 10.5软件, 结合 《中国兽类野外手册》 (Smith和解炎, 2009)、《中国重点陆生野生动物资源 调查》(国家林业局, 2008)、《中国经济动物志(兽类)》 (寿振黄, 1962)、《浙江动物志(兽类)》(董聿茂, 1999)、《安徽兽类志》(王岐山，1990)、《贵州兽类 志》(罗蓉等, 1993)、《广西陆生脊椎动物分布名录》 (周放等, 2011)、《海南岛的鸟兽》(广东省昆虫研究 所动物室和中山大学生物系, 1983)、《台湾哺乳动 物》(祁伟廉, 2016)等动物志书、编目文献、调查文 献，以县域为单位，对中华穿山甲在我国的分布范 围进行数字化，了解该物种在中国的历史分布区。 叠加以上图层, 对比中华穿山甲当前分布、IUCN分 布、历史分布，统计不同省级行政区中华穿山甲的 历史分布与2010-2020年间的出现情况, 并详细记 述2010-2020年间每条确认记录中穿山甲个体被发 现之后的去向, 分析其出没记录的年变化。

针对文献记录中国有分布的3种穿山甲，即中 华穿山甲、印度穿山甲、马来亚穿山甲，从全球生 物多样性信息数据库(Global Biodiversity Information Facility, GBIF)中查询和下载各物种的分布记录 (GBIF Occurrence Download, https://doi.org/10.154 68/dl.7dr738; https://doi.org/10.15468/dl.as4uuq; https: //doi.org/10.15468/dl.sev97a), 整理属名、种名、采 集国家及经纬度等信息，未鉴定到明确物种及经纬 度缺失的数据不予记录, 并根据IUCN物种分布数 据集(https://www.iucnredlist.org/)所提供的各物种分 布范围，排除超出各物种分布边界范围100 km以上 的非野外记录和错误记录位点。基于以上数据绘制 这3种穿山甲的分布图作为参考(附录1)。

\section{2 结果}

经过检索、整理与审核，共收集到2010-2020 
年期间我国境内确认的野生中华穿山甲记录142条, 其中115条来自新闻报道, 18条来自自然保护区、本 文作者实地调查数据等, 8条来自文献记录及标本 平台数据, 1 条来自中国裁判文书网; 其中, 红外相 机拍摄记录25条, 实体记录117条。共记录到中华穿 山甲不少于155只, 影像资料280条(图1)。这些记录 来自 11 个省级行政区(省、自治区、直辖市、特别行 政区)的121个地点(图2)。

中华穿山甲曾广泛分布于中国南方的 18 个省 区。本次调查结果显示, 2010年以来, 其中的11个省 区内有确认的中华穿山甲活动记录, 主要分布于长

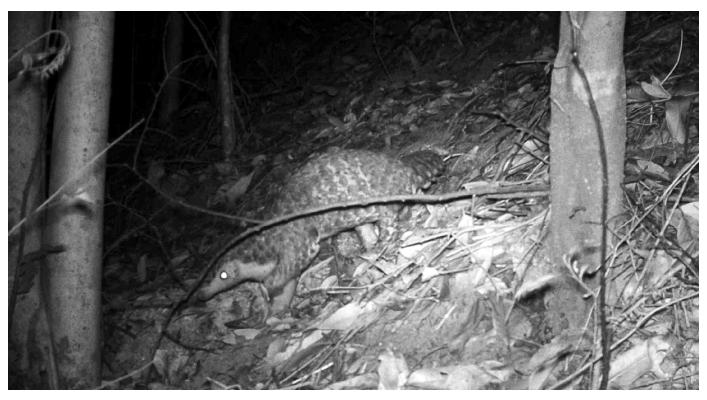

a
江以南(图2)。当前分布范围与IUCN提供的分布区 相近(图2)。就省级行政区而言, 台湾是记录数最多 的地区 (占确认记录总数的 $34.51 \%$ ), 其次是浙江 (19.01\%)和广东(14.08\%) (图3)。近十年来, 中华穿 山甲的记录数量明显呈现逐渐增多的趋势(图4); 其中, 红外相机拍摄记录在近年来增加较多。

在发现的123只实体记录中, 有 $91.06 \%$ (112只) 的个体是在适宜生境范围及周边的人类居住地附 近被居民发现。大多数民众发现中华穿山甲后都选 择了第一时间寻求警察、林业局或救助中心的帮助, 其中 $86 \%$ 的个体(106只)得到救助、放归或未与人接

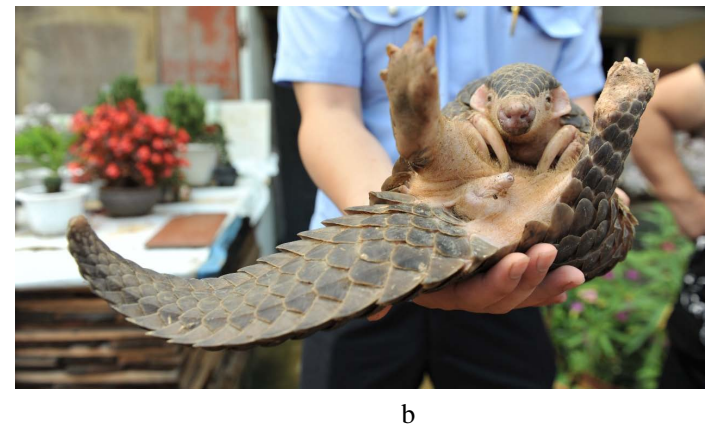

b 谢航凯)。

Fig. 1 Chinese pangolins discovered and rescued in the wild. (a) Chinese pangolin captured by camera trap in Huizhou, Guangdong Province. Provided by Cheng Li; (b) Chinese pangolin been rescued in Chun'an, Zhejiang Province. Photographed by Hangkai Xie.

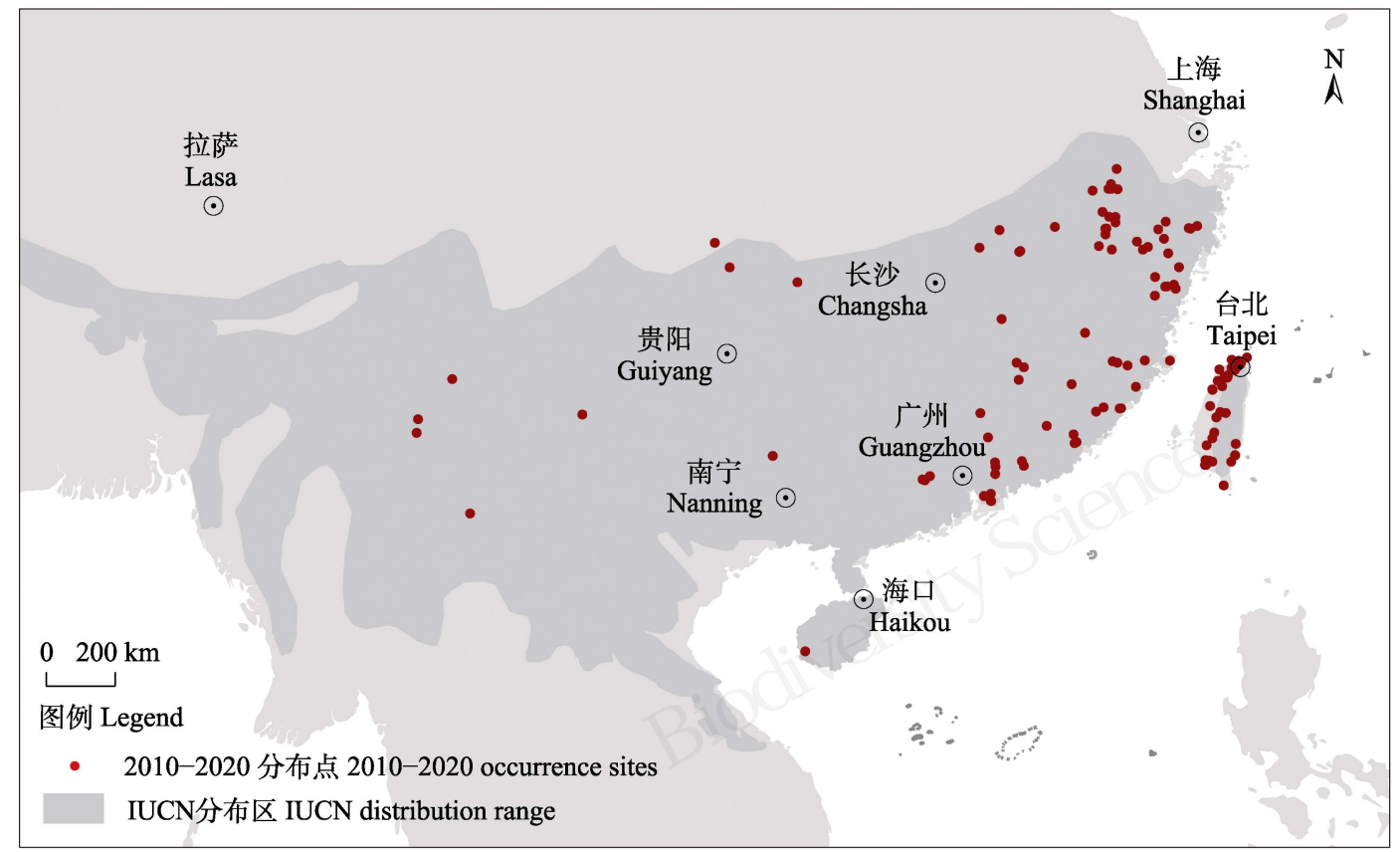

图2 中华穿山甲IUCN分布区与2010-2020年间在中国境内的确认分布位点

Fig. 2 IUCN distribution range and confirmed occurrence sites from 2010 to 2020 of Chinese pangolins in China 


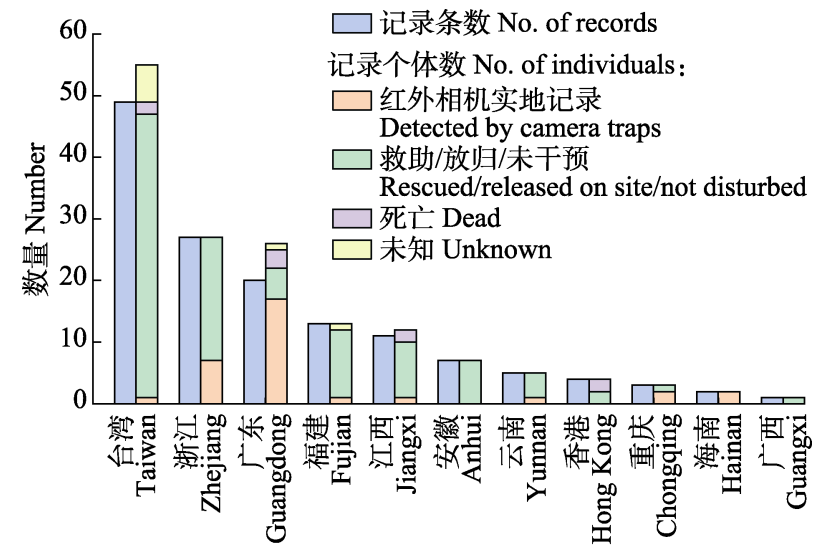

省区 Provinces

图32010-2020年各省区中华穿山甲记录条数、个体数与发 现后去向

Fig. 3 Number of Chinese pangolin records and number of individuals by destination types in each province between 2010 and 2020, China

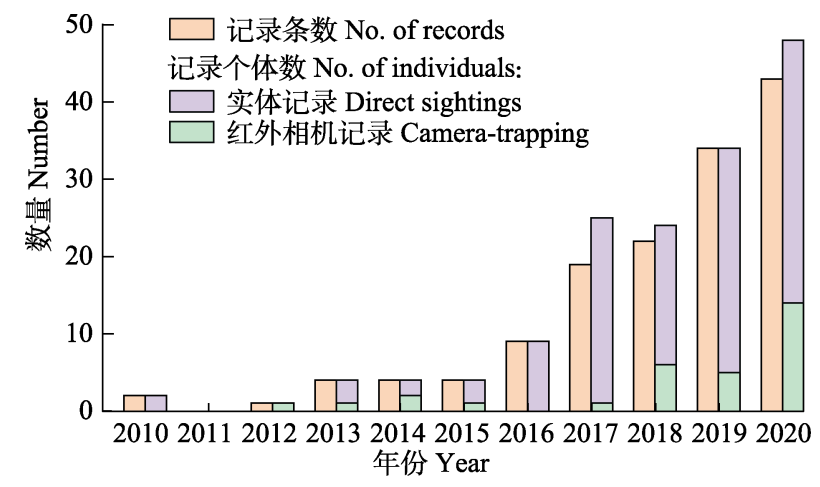

图4 中国境内2010-2020年中华穿山甲记录条数、个体数与 记录类型

Fig. 4 Number of Chinese pangolin records and number of individuals recorded by recording types in each year between 2010 and 2020, China

触, 8只死亡, 其他后续状态不明。

\section{3 讨论}

由于传统中医药的需求和部分人对野生动物 食品、制品的需求, 我国曾是穿山甲及其制品的最 大消费国之一(Challender et al, 2015)。相关省市的 药材部门统计结果显示, 20 世纪60年代前后我国穿 山甲年捕获量为15-16万只; 此后直至90年代之前, 我国市场所消耗的穿山甲主要依靠国内捕获(尹峰 等, 2016)。随后中华穿山甲的野外种群数量开始下 降; 据统计，90年代穿山甲年捕获量降至数千只(汪 松，1998)。随后我国的穿山甲及其制品的贸易货源 则主要依靠马来西亚、印度尼西亚和越南等国
(Heinrich et al, 2016), 并逐渐延伸至非洲分布的长 尾穿山甲属和地穿山甲属物种。2020年，我国将穿 山甲属动物由国家二级重点保护野生动物提升至 一级(国家林业和草原局和农业农村部，2020)；与 此同时，新版的《中国药典》将穿山甲除名; 随后， 全国人大常委会通过的《关于全面禁止非法野生动 物交易、革除滥食野生动物陃习、切实保障人民群 众生命健康的决定》，进一步打击了野生动物非法 贸易, 将有力促进我国中华穿山甲的相关研究与保 护(梁智健等, 2020)。

根据文献与历史记录显示，中华穿山甲曾广泛 分布于我国南方各省，历史上以福建、广东、广西、 云南、贵州、海南、湖南、台湾为多(张立等, 2010)。 但本次调查发现，部分曾有穿山甲分布的地区，如 四川、贵州、湖南、湖北等地，过去10年间均未见 有中华穿山甲的确认记录。相比其历史分布区，中 华穿山甲近年来在西南、华南地区的野外确认记录 匮乏，该物种在这些地区的分布与种群现状亟待进 一步调查。近10年来缺少全国范围的野生穿山甲资 源普查数据, 使得我们难以及时、准确掌握中华穿 山甲的种群现状、分布范围及其变化趋势，在该物 种的保护管理及有针对性的保护行动规划中面临 基础数据与信息贵乏的困难。由于中华穿山甲具有 活动隐秘、数量稀少的特点, 因此建议结合我国目 前已经广泛建立的红外相机监测平台与体系(李戟 等, 2014; 李晟, 2020), 在其历史分布区及潜在分布 区内开展专项本底调查, 同时结合公众科学(citizen science)记录、民间调查、社区巡护等工作，排查中 华穿山甲的分布情况，分析其分布区变化并评估栖 息地环境情况。

本次调查结果显示，在我国的台湾、广东、浙 江3省中华穿山甲出没记录较多, 部分位点多次发 现，表明这些地区目前仍具有一定数量的野生种群 分布。从记录来源可以看到, 本研究中所收集到的 中华穿山甲记录大多为各地的零星报道，此前还未 有学术研究对这些记录进行系统的总结、更新。在 国际生物多样性数据库(例如全球生物多样性信息 数据库GBIF)中, 除台湾地区外, 中国大陆与海南 岛的中华穿山甲记录数量较少且缺乏对记录类型、 记录来源的详细描述，难以支持对该物种现状的可 靠评估。因此，建议有关管理部门在以上地区开展 有针对性的专项调查，同时与IUCN物种评估专家 
组、GBIF等国际组织和数据平台加强交流和信息共 享, 加大针对中华穿山甲及其栖息地的保护力度, 为其现状评估提供更为全面可靠的数据支撑。

本研究记录到的中华穿山甲个体中, 有相当比 例的个体在被人发现后送交了当地的野生动物救 护单位, 其中部分个体在被发现时存在因多种原因 所导致的伤、病问题。因此, 建议野生穿山甲分布 地区的野生动物救护单位与相关科研机构合作, 深 入开展中华穿山甲的伤病救助治疗与迁地保护的 研究, 提升救助效率。此外, 近年来我国海关与相 关执法部门还查获从国外走私入境的活体穿山甲, 包括马来穿山甲、印度穿山甲等。由于马来穿山甲 和印度穿山甲在我国境内的分布现状还不甚清楚, 对于这些不是来自国内原生栖息地的穿山甲活体, 选择在哪里以及如何进行野外放归需谨慎处理, 应 进行科学、严谨的论证。在今后野外发现穿山甲的 报道中, 也需对所发现的穿山甲个体进行仔细的鉴 定与识别, 以明确所记录穿山甲的种类。

近10年来, 越来越多的中华穿山甲在中国野外 被发现, 尤其是在2016年之后明显呈现逐渐增多的 趋势。这得益于有关部门执法力度加强和民众保护 意识的提高。与此同时, 越来越多的自然保护地开 始使用红外相机技术, 加强了对穿山甲分布区内野 生动物的调查、监测及栖息地保护(李晟, 2020), 红 外相机拍摄记录逐渐增加。例如, 浙江省乌岩岭自 然保护区(章书声等, 2017)、钱江源国家公园(申小 莉等, 2020), 云南省西双版纳国家级自然保护区(贺 如川等, 2020), 海南省尖峰岭国家级自然保护区(李 佳等, 2020)等, 分别在鸟兽的红外相机本底调查与 监测中记录到中华穿山甲; 广东省近年来先后在肇 庆、韶关、河源、潮州、梅州、惠州等地使用红外 相机监测记录到多只次的中华穿山甲(例如: 范宗 骥等, 2019, 2020; 万雅琼等, 2020)。

令人欣慰的是, 本次调查中收集到的案例与信 息显示, 我国民众对于穿山甲的认知和保护意识近 年来有了较大的提高, 政府机构、非政府保护组织、 专家学者、保护地工作人员以及当地社区群众都为 保护工作做出了贡献, 尤其是当地群众在发现、救 助穿山甲的过程中发挥了很大作用。尽管如此, 我 们仍需要意识到, 受利益驱动的非法穿山甲贸易可 能仍然存在且愈加隐蔽, 因此应多方加强对其栖息 地的巡查保护, 促进分布区周围城乡社会经济与生
态保护协同发展(刘静等, 2010)。同时, 野生动物主 管部门应就穿山甲的发现上报、救助、放归等流程 制定明确的管理办法, 制定伤病动物的救助预案, 并通过多种渠道加强宣传教育和科普工作, 减少由 于捕猎、消费或不恰当救助行为(Daut et al, 2015; 吕忠梅和陈真亮, 2020), 通过奖励发现和救助穿山 甲, 以及举报和惩罚非法买卖行为等方式约束和引 导民众行为(Tyrrell et al, 2017)。

致谢: 感谢美境自然张颖溢博士为本研究提供的穿 山甲野外记录信息。感谢参与穿山甲调查和保护的 一线研究者和当地居民。感谢北京大学朱淑怡、刘 鸣章在历史分布地图数字化和数据分析中提供的 帮助。感谢浙江省淳安县汾口镇谢航凯提供中华穿 山甲救助照片。感谢论文审稿人在审稿过程中提出 的宝贵意见及提供的重要信息, 为文章的修改与完 善提供了非常大的帮助。

\section{ORCID}

孔玥峤 (D) https://orcid.org/0000-0002-0622-1635

李晟 (D) https://orcid.org/0000-0001-7200-9539

\section{参考文献}

Animal Department of Guangdong Institute of Entomology, School of Life Sciences of Sun Yat-sen University (1983) Animals and Birds in Hainan Island. Science Press, Beijing. (in Chinese) [广东省昆虫研究所动物室, 中山大学生物系 (1983) 海南岛的鸟兽. 科学出版社, 北京.]

Challender DWS, Harrop SR, MacMillan DC (2015) Understanding markets to conserve trade-threatened species in CITES. Biological Conservation, 187, 249-259.

Challender DWS, Wu SB, Kaspal P, Khatiwada AP, Ghose A, Sun CN, Mohapatra RK, Laxmi ST (2019) Manis pentadactyla (errata version published in 2020). The IUCN Red List of Threatened Species 2019: e.T12764A168392151. https://dx.doi.org/10.2305/IUCN.UK.2019-3.RLTS.T12764 A168392151.en. (accessed on 2021-01-25)

Cheng WD, Xing S, Bonebrake TC (2017) Recent pangolin seizures in China reveal priority areas for intervention. Conservation Letters, 10, 757-764.

Chinese Pharmacopoeia Commission (2020) Chinese Pharmacopoeia. China Medical Science Press, Beijing. (in Chinese) [国家药典委员会 (2020) 中华人民共和国药典. 中国医 药科技出版社, 北京.]

Daut EF, Brightsmith DJ, Peterson MJ (2015) Role of nongovernmental organizations in combating illegal wildlife-pet trade in Peru. Journal for Nature Conservation, 24, 72-82. 
Dong YM (1999) Animals of Zhejiang (Mammals). Zhejiang Science and Technology Publishing House, Hangzhou. (in Chinese) [董聿茂 (1999) 浙江动物志(兽类). 浙江科学技 术出版社, 杭州.]

Fan ZJ, Ouyang XJ, Bai WK, Huang ZL, Cheng DH, Li JQ (2019) Rediscovery of Chinese pangolin (Manis pentadactyla) in the Zhaoqing Region, Guangdong Province. Chinese Journal of Wildlife, 40, 811-813. (in Chinese with English abstract) [范宗䩀, 欧阳学军, 白文科, 黄忠良, 程 德洪, 李佳琦 (2019) 广东肇庆地区再现中华穿山甲. 野 生动物学报, 40, 811-813.]

Fan ZJ, Ouyang XJ, Wan YQ, Xiao WH, Xie WG, Ou SK, Deng XJ, Huang ZL, Xiao ZS (2020) Mammals and birds survey using camera-trapping in Dinghushan and its surrounding forests, Guangdong Province. Biodiversity Science, 28, 1147-1153. (in Chinese with English abstract) [范宗骥, 欧阳学军, 万雅琼, 肖文宏, 谢文贵, 欧世坤, 邓锡杰，黄忠良，肖治术 (2020) 基于红外相机技术对广 东鼎湖山及其周边林地的鸟兽调查. 生物多样性, 28 , 1147-1153.]

Gaudin TJ, Emry RJ, Wible JR (2009) The phylogeny of living and extinct pangolins (Mammalia, Pholidota) and associated taxa: A morphology based analysis. Journal of Mammalian Evolution, 16, 235-305.

He RC, Wang L, Quan RC (2020) Introduction to Transboundary Animal Diversity Monitoring Platform of Southern Yunnan, China and Southeast Asia. Biodiversity Science, 28, 1097-1103. (in Chinese with English abstract) [贺如川, 王林, 权锐昌 (2020) 中国滇南-东南亚跨境动物多样性 监测平台概述. 生物多样性, 28, 1097-1103.]

Heinrich S, Wittmann TA, Prowse TAA, Ross JV, Delean S, Shepherd CR, Cassey P (2016) Where did all the pangolins go? International CITES trade in pangolin species. Global Ecology and Conservation, 8, 241-253.

Hua LS, Gong SP, Wang FM, Li WY, Ge Y, Li XN, Hou FH (2015) Captive breeding of pangolins: Current status, problems and future prospects. Zookeys, 507, 99-114.

Jiang ZG, Liu SY, Wu Y, Jiang XL, Zhou KY (2017) China's mammal diversity (2nd edition). Biodiversity Science, 25, 886-895. (in Chinese with English abstract) [蒋志刚, 刘少 英, 吴毅, 蒋学龙, 周开亚 (2017) 中国哺乳动物多样性 (第2版). 生物多样性, 25, 886-895.]

Jiang ZG, Ma Y, Wu Y, Wang YX, Zhou KY, Liu SY, Feng ZJ (2015) China's Mammal Diversity and Geographic Distribution. Science Press, Beijing. (in Chinese) [蒋志刚, 马勇, 吴毅, 王应祥, 周开亚, 刘少英, 冯祚建 (2015) 中国哺乳动物多样性及地理分布. 科学出版社, 北京.]

Li J, Wang XL, Yang MW, Chen DX, Wang XJ, Luo P, Liu F, Xue YD, Li GL, Zhang YG, Zhang Y, Li DQ (2020) Construction progress of camera-trapping database from the Nature Reserves Biological Specimen Resources Sharing Sub-platform. Biodiversity Science, 28, 1081-1089. (in Chinese with English abstract) [李佳, 王秀䂞, 杨明伟, 陈
大祥, 王晓菊, 罗平, 刘芳, 薛亚东, 李广良, 张于光, 张 宇, 李迪强 (2020) 自然保护区生物标本资源共享子平 台红外相机数据库建设进展. 生物多样性, 28, 10811089.]

Li S (2020) Development progress and outlook of the wildlife camera-trapping networks in China. Biodiversity Science, 28, 1045-1048. (in Chinese) [李晟 (2020) 中国野生动物 红外相机监测网络建设进展与展望. 生物多样性, 28, 1045-1048.]

Li S, Wang DJ, Xiao ZS, Li XH, Wang TM, Feng LM, Wang $Y$ (2014) Camera-trapping in wildlife research and conservation in China: Review and outlook. Biodiversity Science, 22, 685-695. (in Chinese with English abstract) [李 晟, 王大军, 肖治术, 李欣海, 王天明, 冯利民, 王云 (2014) 红外相机技术在我国野生动物研究与保护中的应 用与前景. 生物多样性, 22, 685-695.]

Liang ZJ, Hu JB, Hu SF, Zhao JJ, Zhou KW, Jiao YB, Huang C, He X, Wan AKY, Li LS, Hua FY, Lee TM (2020) Understanding and changing wildlife consumption behavior from a multidisciplinary perspective. Biodiversity Science, 28, 606-620. (in Chinese with English abstract) [梁智健, 胡佳贝, 胡思帆, 赵晶晶, 周凯文, 焦运波, 黄程, 何霞, 温嘉恩, 李立姝, 华方圆, 李添明 (2020) 多学科视角下 的野生动物消费需求和消费行为研究进展. 生物多样性, 28, 606-620.]

Liu SY, Wu Y, Li S (2020) Handbook of the Mammals of China, 2nd edn. The Straits Publishing \& Distributing Group, Fuzhou. (in Chinese) [刘少英, 吴毅, 李晟 (2020) 中国兽类图鉴(第二版). 海峡出版发行集团, 福州.]

Liu J, Ouyang ZY, Miao H, Xu WH (2010) Sustainable development between protected areas and the adjacent communities. China Population, Resources and Environment, 20, 109-114. (in Chinese with English abstract) [刘 静, 欧阳志云, 苗鸿, 徐卫华 (2010) 自然保护区与周边 社区的可持续发展. 中国人口・资源与环境, 20, 109-114.]

Luo R (1993) Mammals of Guizhou. Guizhou Science and Technology Publishing House, Guiyang. (in Chinese) [罗蓉 (1993) 贵州兽类志. 贵州科技出版社, 贵阳.]

Lü ZM, Chen ZL (2020) Revision of the Law of the People's Republic of China on the Protection of Wildlife: Background, issues and suggestions. Biodiversity Science, 28, 550-557. (in Chinese with English abstract) [吕忠梅, 陈真亮 (2020) 《野生动物保护法》再修订: 背景、争点 与建议. 生物多样性, 28, 550-557.]

Qi WL (2016) A Field Guide to Mammals in Taiwan. Commonwealth Publishing Ltd., Taipei. (in Chinese) [祁伟 廉 (2016) 台湾哺乳动物. 远见天下文化出版股份有限 公司, 台北.]

Shen XL, Yu JP, Li S, Xiao HY, Chen XN, Chen SW, Liu MZ, Ma KP (2020) Progress overview of the camera-trapping monitoring platform for the Qianjiangyuan National Park, Zhejiang Province. Biodiversity Science, 28, 1110-1114. (in Chinese with English abstract) [申小莉, 余建平, 李晟, 肖 
慧芸, 陈小南, 陈声文, 刘鸣章, 马克平 (2020) 钱江源 国家公园红外相机监测平台进展概述. 生物多样性, 28, 1110-1114.]

Shou ZH (1962) Economic Fauna of China (Mammals). Science Press, Beijing. (in Chinese) [寿振黄 (1962) 中国 经济动物志(兽类). 科学出版社, 北京.]

Smith A, Xie Y (2009) A Guide to the Mammals of China. Hunan Education Publishing House, Changsha. (in Chinese) [Smith A, 解炎 (2009) 中国兽类野外手册. 湖南教育出 版社, 长沙.]

State Forestry Administration of the People's Republic of China (2008) Resource Investigation of Key Terrestrial Wildlife in China. China Forestry Publishing House, Beijing. (in Chinese) [国家林业局 (2008) 中国重点陆生 野生动物资源调查. 中国林业出版社, 北京.]

Tyrrell P, Russell S, Western D (2017) Seasonal movements of wildlife and livestock in a heterogenous pastoral landscape: Implications for coexistence and community based conservation. Global Ecology and Conservation, 12, 59-72.

Wan YQ, Li JQ, Yang XW, Li S, Xu HG (2020) Progress of the China mammal diversity observation network (China BON-Mammal) based on camera-trapping. Biodiversity Science, 28, 1115-1124. (in Chinese with English abstract) [万雅琼, 李佳琦, 杨兴文, 李晟, 徐海根 (2020) 基于红 外相机的中国哺乳动物多样性观测网络建设进展. 生物 多样性, 28, 1115-1124.]

Wang QS (1990) Mammals of Anhui. Anhui Science and Technology Publishing House, Hefei. (in Chinese) [王岐山 (1990) 安徽兽类志. 安徽科学技术出版社, 合肥.]

Wang S (1998) China Red Data Book of Endangered Animals. Science Press, Beijing. (in Chinese) [汪松 (1998) 中国濒 危动物红皮书: 兽类. 科学出版社, 北京.]

Wang YX (2003) A Complete Checklist of Mammal Species and Subspecies in China: A Taxonomic and Geographic Reference. China Forestry Publishing House, Beijing. (in Chinese) [王应祥 (2003) 中国哺乳动物种和亚种分类名 录与分布大全. 中国林业出版社, 北京.]

Wu SB, Ma GZ, Tang M, Chen H, Liu NF (2002) The status and conservation strategy of pangolin resource in China. Journal of Natural Resources, 17, 174-180. (in Chinese with English abstract) [吴诗宝, 马广智, 唐玫, 陈海, 刘迺发 (2002) 中国穿山甲资源现状及保护对策. 自然资源学报, 17, 174-180.]

Yang CW, Chen SM, Chang CY, Lin MF, Block E, Lorentsen
R, Chin JSC, Dierenfeld ES (2007) History and dietary husbandry of pangolins in captivity. Zoo Biology, 26, 223-230.

Yang L, Chen MH, Challender DWS, Waterman C, Zhang C, Huo ZM, Liu HW, Luan XF (2018) Historical data for conservation: Reconstructing range changes of Chinese pangolin (Manis pentadactyla) in Eastern China (1970-2016). Proceedings of the Royal Society B: Biological Sciences, 285, 20181084.

Yin F, Lu LL, Meng M, Liu DZ (2016) Trade and conservation of pangolin. Chinese Journal of Wildlife, 37, 157-161. (in Chinese with English abstract) [尹峰, 卢琳琳, 梦梦, 刘定 震 (2016) 穿山甲的贸易与保护. 野生动物学报, 37, 157-161.]

Yu JY, Peng JJ, Liao GY (2016) A preliminary survey on ecological geographical distribution and resource status of the Chinese pangolin in Chongqing. Forest Science and Technology, (6), 41-43. (in Chinese) [余经裕, 彭建军, 廖 国宇 (2016) 重庆市中华穿山甲的生态地理分布及资源 现状调查初报. 林业科技通讯, (6), 41-43.]

Zhang L, Li QL, Sun G, Luo SJ (2010) Population profile and conservation of pangolin. Bulletin of Biology, 45(9), 1-4. (in Chinese) [张立, 李麒麟, 孙戈, 罗述金 (2010) 穿山 甲种群概况及保护. 生物学通报, 45(9), 1-4.]

Zhang L, Wu SB, Bao Y (2009) Current status of Chinese pangolin (Manis pentadactyla) in the wild: A rapid range wide population assessment. In: Proceedings of the Workshop on Trade and Conservation of Pangolins Native to South and Southeast Asia, 30 June 2 July 2008, Singapore Zoo, Singapore (eds Pantel S, Chin SY). TRAFFIC Southeast Asia, Petaling Jaya, Selangor, Malaysia.

Zhang SS, Zheng FD, Li JQ, Bao QM, Lai JH, Cheng HY (2017) Monitoring diversity of ground-dwelling birds and mammals in Wuyanling National Nature Reserve using infrared camera traps. Biodiversity Science, 25, 427-429. (in Chinese) [章书声, 郑方东, 李佳琦, 包其敏, 赖家厚, 程宏毅 (2017) 基于红外相机技术对乌岩岭国家级自然 保护区地面鸟兽的初步调查. 生物多样性, 25, 427-429.]

Zhou F (2011) List of Terrestrial Vertebrates in Guangxi. China Forestry Publishing House, Beijing. (in Chinese) [周 放 (2011) 广西陆生脊椎动物分布名录. 中国林业出版 社, 北京.]

(责任编委: 蒋志刚 责任编辑: 时意专)

\section{附录 Supplementary Material}

附录1 文献记录中国有分布的3种穿山甲的IUCN分布范围与GBIF中的记录点

Appendix 1 Distribution ranges from IUCN and occurrence sites from GBIF of the three pangolin species which are once recorded in literature in China

https://www.biodiversity-science.net/fileup/PDF/2020446-1.pdf 
孔玥峤, 李晟, 刘宝权, 周佳俊, 李成, 余建平 (2021) 2010-2020年中华穿山甲在中国的发现记录及保护现状. 生物多样性, 29, 910-917.

http://www.biodiversity-science.net/CN/10.17520/biods.2020446

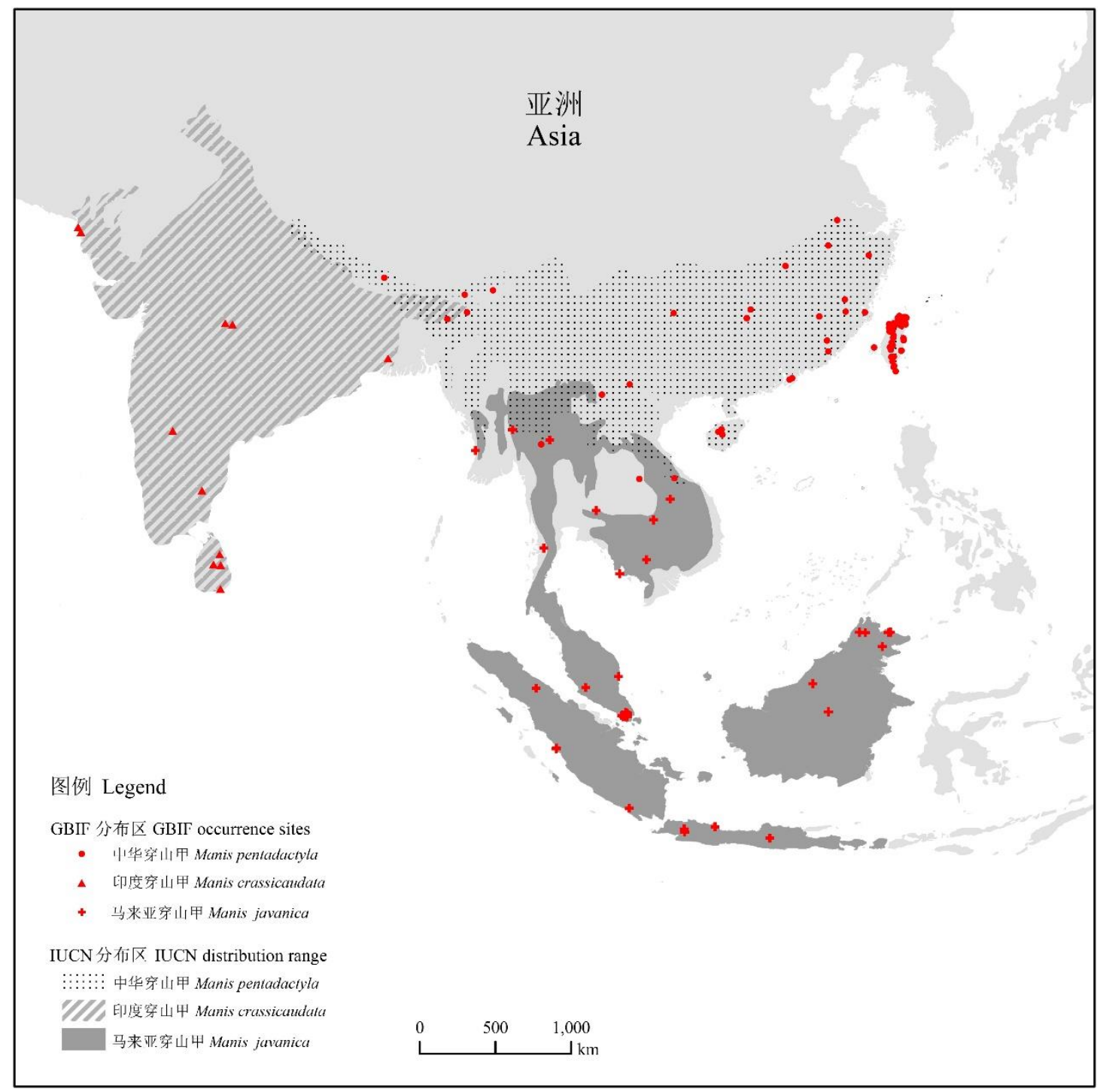

附录1 文献记录中国有分布的3种穿山甲的IUCN分布范围与GBIF中的记录点

Appendix 1 Distribution ranges from IUCN and occurrence sites from GBIF of the three pangolin species which are once recorded in literature in China 